\title{
Comment
}

\section{CLAYTON SECTION 7 AND THE DUPONT-GM CASE: A "BIG STICK" FOR ANTITRUST?}

Out of the 1957 term of the Supreme Court of the United States have come many provocative and controversial decisions. One that created the greatest furor in the business community was United States v. E.I. duPont de Nemours \& Co. et $a l^{1}$ where four justices ${ }^{2}$ held that du Pont's 23 per cent stock holding in General Motors Corporation was illegal as a violation of the anti-merger provisions of section 7 of the Clayton Act. The decision was so far-reaching, the dissent felt, that, " 40 years after the enactment of the Clayton Act, it now becomes apparent for the first time that $\$ 7$ has been a sleeping giant all along." 3 The tumult having subsided, it is time to appraise the situation and determine what the "sleeping giant" has become.

As originally enacted in 1914, section 7 of the Clayton Act provided: 4

no corporation engaged in commerce shall acquire, directly or indirectly, the whole or any part of the stock or other share capital of another corporation engaged also in commerce, where the effect of such acquisition may be to substantially lessen competition between the corporation whose stock is so acquired and the corporation making the acquisition, or to restrain such commerce in any section or community, or tend to create a monopoly of any line of commerce.

The section was limited in application solely to stock acquisitions and by interpretation was generally thought to apply solely to horizontal acquisitions. ${ }^{5}$ In addition, an ambiguity in the terms of the section which apparently prohibited the acquisition of stock of competing firms irrespective of their size persuaded the courts to read into the section the Sherman Act rule of reason. ${ }^{\circ}$

1353 U.S. 586 (1957) (heremafter referred to as the du Pont-GM decision). The 'et al' included, among others, General Motor Corporation, United States Rubber Company, Christiana Securities Company, Delaware Realty \& Investment Corporation, Pierre S. du Pont, Lammont du Pont, Irenee du Pont, and other members of the du Pont family. The action was originally commenced in 1949 in the District Court for the Northern District of Illinois and, following a dismissal, a direct appeal was taken to the Supreme Court. The lower court opinion is reported in $126 \mathrm{~F}$. Supp. 235 (1954).

2 Mr. Justice Brennan delivered the majority opinion joined by Chief Justice Warren and Justices Black and Douglas; Justices Burton and Frankfurter dissented and Justices Clark, Harlan, and Whittaker took no part in the consideration of the case.

3353 U.S. at 611 .

438 Stat. 731 (1914).

5 Federat Trade Commission, Report on Corporate Mergers and Acquisitions 168 (1955).

6 International Shoe Co. v. FTC, 280 U.S. 291 (1930), is generally cited as the start of the infusion of the Sherman Act 'rule of reason' test into $\$ 7$ actions. See, e.g., REPORT OF THE Atrorney General, Study of the Antitrust Laws 118 (1955). But later cases more closely approximate the Sherman Act test in apphication. See Temple Anthracite Coal Co. v. FTC, 51 F.2d 656 (3d Cir. 1931); Pennsylvania R.R. v. ICC, 66 F.2d 37 (3d Cir. 1933); United States v. Republic Steel Corp., 11 F. Supp. 117 (N.D. Ohio 1935).

In the International Shoe case, one of the nation's largest manufacturers of shoes had acquired all of the stock of another company also engaged in the manufacture of shoes. However, the Court found that over $95 \%$ of the production of each company was sold in different markets and held that the elimination of competition in only $5 \%$ of the national market was not forbidden. The Court approved a test apphed in a lower court case, Standard Oil Co. v. FTC, 282 Fed. 81, 87 (1922), that the standard of legality was the absence or presence of 
In 1950 , section 7 was substantially amended to clarify the ambiguity and to broaden its scope. Under "new" section 7, asset acquisitions, as well as those of stock, are expressly made subject to the act. ${ }^{7}$ The committee reports make it clear that the section applies to vertical and conglomerate acquisitions as well as horizontal. ${ }^{8}$ Although the revised section carries over intact the prohibition against acquisitions which tend to create a monopoly, the ambiguous language has been replaced; acquisitions are prohibited "where in any line of commerce in any section of the country, the effect of such acquisition may be substantially to lessen competition..." The express purpose of the new test was to eliminate the Sherman Act rule of reason from section 7 application. ${ }^{10}$

With this evolution of section 7 in the background, the decision in the $d u$ PontGM case was handed down in 1957, the first Supreme Court decision on section 7 since the 1930 decision in the International Shoe case. ${ }^{11}$ Although the Court decided the case under old section $7,{ }^{12}$ the decision is important in two respects. First, it provides the most recent ruling of the "tend to create a monopoly" test of section 7 which remains substantially unchanged after the 1950 amendments. Second, it may furnish a guide to the approach to be taken by the courts in applying other tests of new section $7 .^{13}$

The crux of the decision in the $d u$ Pont-GM case may be stated briefly. In spite of the fact that section 7 had never been applied to vertical acquisitions before, the legislative intent of the original act and that of the amendment persuaded the Court that such acquistions were within the purview of the act. ${ }^{14}$ Further, it was held that section 7 was not limited in apphication to the time of the acquisition itself, but applied at any time the acquisition threatened to ripen into the prohibited effects. ${ }^{15}$ Having defined the test of "tend to create a monopoly" as the

prejudice to the public interest by unduly restricting competition or unduly obstructing the due course of trade, admittedly the Sherman Act test. 280 U.S. at 298 . This became the settled construction of the "substantially lessen" test of $\S 7$, the courts reasoning that the acquisition by one company of control of its competitor would not merely lessen competition, it would eliminate it completely. Therefore, a "substantial lessening of competition" must refer to an effect on the entire market in which the firms did busimess. In effect, this read out of Clayton $\S 7$ the first test and left ouly the tests "... to restrain such commerce in any section or commumity, or tend to create a monopoly of any line of commerce."

7 "[N]o corporation ... shall acquire the whole or any part of the assets of another corporation . . . " 64 STAT. 1126 (1950), 15 U.S.C. $\$ 18$ (1952 ed.). By this provision, Congress sought to close a loophole in the old section whereby acquisitions of stock, followed by conversion into assets, or acquisitions completely by assets were beyond attack. See H.R. Rep. No. 1191, 81st Cong., 1st Sess. 12 (1949) ; S. Rep. No. 1775, 81st Cong., 2d Sess. 3-4 (1950).

8 H.R. Rep. No. 1191, 81st Cong., 1st Sess. 11 (1949).

864 STAT. 1126 (1950); 15 U.S.C. \$ 18 (1952 ed.).

10 See S. Rep. No. 1775, 81st Cong., 2d Sess. 4-5 (1950); Report of the AtTorner GeNENAL, STUDY OF THE ANTITRUST LAws 117-18 (1955).

11 International Shoe Co. v. FTC, 280 U.S. 291 (1930).

12 The Court interpreted the 1950 Amendments as prospective in effect only and therefore not applicable to acquisitions prior thereto. 353 U.S. at $588 \mathrm{n} .4$. However, serious doubts exist as to the validity of this position, see text discussion beginning at part III infra.

13 See, e.g., U.S. News \& World Report, June 14, 1957, p. 125 (inany businessmen . . . feel that this historic ruling has other important meanings for the future. The decision . . . could mean that the present Supreme Court is more willing . . . to break up or prevent business combination.).

14353 U.S. at 590-92. The dissent reaclied the opposite conclusion on equally ambiguous legislative intent and on 40 years of administrative practice. $7 d$. at 611-19.

15 Id. at 596-98. Again the dissent reached the opposite conclusion by a different interpretation of the language of $\S 7 . I d$. at $619-26$. The respective positions of the majority and the dissent on this issue are treated more extensively in text in Part III infra. 
power to foreclose competition from a substantial share of a substantial market, the Court concluded that, at the time of the suit, du Pont's 23 per cent stock acquisition made in 1917-1919 presented a reasonable likelihood of the creation of a monopoly in the market for auto finishes and fabrics. ${ }^{16}$

Since the facts of the case will support completely contradictory conclusions according to one's individual predilictions, ${ }^{17}$ the merits of $d u$ Pont-GM will not be discussed. Rather, the attempt will be to analyze the Court's interpretation of section 7 and predict the possible consequences to the busmess community. For purposes of analysis, three distinct questions are presented: (1) What market effects are forbidden by section 7 ? (2) Assuming that the requisite market effects are present, how large an acquisition as a measure of control is necessary to establish a violation? (3) What will be the consequences of the $d u$ Pont-GM holding that the test of section 7 may be applied at the time of the suit?

\section{I}

\section{TEST OF MARKET EFFECT}

As now worded, an acquisition will violate section 7 "where the effect of such acquisition may be substantially to lessen competition, or to tend to create a monopoly of any line of commerce." The Senate Judiciary Committee commented on the revised section as follows: 18

By eliminating the provisions of the existing section tlat appear to reach situations of little economic significance, it is the purpose of this legislation to assure a broader construction of the more fundamental provisions that are retained than has been given in the past. The committee wishes to make it clear that the bill is not intended to revert to the Slierman Act test. The intent here, as in other parts of the Clayton Act, is to cope with monopolistic tendencies in their incipiency and well before they have attained such effects as would justify a Sherman Act proceeding.

Two distinct tests are established: (A) where the effect of an acquisition may be substantially to lessen competition, and (B) where the effect of an acquisition may be to tend to create a monopoly in any line of commerce.

\section{A. Substantial lessening of competition.}

Under the new wording of the section, it seems clear that Congress intended to establish a measure related to the degree of anti-competitive effects produced or threatened to be produced by the acquisition. The test is no longer limited to the effect of an acquisition on the relationship between the acquiring and acquired

16353 U.S. at 592-96. The relevant market was defined as the market for automotive finishes and fabrics. The court felt that a market comprising the auto industry must be substantial and since GM's share represented almost 50\% of that market it must be a substantial one.

The dissent established the market as total finishes and fabrics and, when tested against these figures, concluded that GM's share was insubstantial. In any event, the dissent felt that the evidence did not disclose the foreclosure of competition at all. Id. at 647-54.

17 Compare Markham, The Du Pont-General Motors Decision, 43 VA. L. Rev. 881, 883 (1957) (virtually every finding of fact by the district court which the Supreme Court cited in support of its opinion can be reduced to a single economic fact-between 1917 . . . and 1949, ... General Motors' share of the automobile market increased from 11 per cent to nearly 50 per cent) with Adelman, The du Pont General Motors Decision, id. 873, 875 (never again will there be a comparable opportunity for judicial rodomontade over corporate bigness. The majority opinion is alniost completely free of it).

18 S. Rep. No. 1775, 81st Cong., 2d Sess. 4-5 (1950). 
corporations, although it is clear that this relationship remains important. The best way to state the test is perhaps to define its limits, for, as with any measure of market effects, the ultimate determination will turn upon the degree of anticompetitive effects resulting under the particular circumstances.

At one extreme is the expressed intent to avoid the Sherman Act tests. The report of the House Judiciary Committee makes it clear that this means two things: first, that only a probability of the prohibited effects is required for violation of section 7, not proof of actual effects; ${ }^{19}$ and second, that section 7 may be violated by an acquisition whose effect is a lesser reduction of competition than would be required for a violation of the Sherman Act. ${ }^{20}$ At the other extreme, the amended section is not intended to prevent the merger of small companies which have inconsequential shares of the market or whose competitors are so numerous that the acquisition would have no perceptible effect on the imtensity of competition.21

Since the enactment of the 1950 amendment, two cases and an FTC opinion have interpreted and applied section 7. Both cases involved horizontal acquisitions of part of the stock of a competitor. Leaving aside the problem of control that is, the ability to affect the market at all ${ }^{22}$-the question of main concern was whether the threatened effect on the market would amount to a "substantial lessening of competition." Hamilton Watch Co. v. Benrus Watch Co. ${ }^{23}$ involved two leading manufacturers of jeweled watches, ranking fifth and third respectively among the top six producers who in total supplied over 90 per cent of the market. Each company supplied about 10 per cent of the national market and, although Hamilton watches generally sold at a higher price than Benrus, the court found that 70 per cent of Hamilton and 96 per cent of Benrus watches sold for less than $\$ 70.00$-thus establishing that the major portion of each company's products were in direct competition. The court concluded that an outright merger of the two companies would by eliminating competition in 20 per cent of the market substantially lessen competition in violation of section $7 . .^{24}$

The American Crystal Sugar Co. v. Cuban-American Sugar Co. ${ }^{25}$ case presented a similar situation. Although both companies generally sold in separate parts of the nation-the plaintiff in the western states and the defendant in the eastern states-the court found that their selling areas overlapped in the ten states around the Mississippi River. Within this geographical market, their com-

19 "Thus, it would be unnecessary for the Government to speculate as to what is in the 'back of the minds' of those who promote a merger; or to prove that the acquiring firm had engaged in actions which are considered to be unethical or predatory; or to show that as a result of a merger the acquiring firm had already obtained stuch a degree of control that it possessed the power to destroy or exclude competitors or fix prices." H.R. Rep. No. 1191, 81st Cong., 1st Sess. 8 (1949).

20 "Acquisitions of stock or assets have a cumulative effect, and control of the market sufficient to constitute a violation of the Sherman Act may be achieved not in a single acquisition but as the result of a series of acquisitions. The bill is imtended to permit intervention in such a cumulative process when the effect of an acquisition may be a significant reduction in the vigor of competition, even though this effect may not be so far-reaching as to amount to a combination in restraint of trade, create a monopoly, or constitute an attempt to monopolize." Ibid.

21 Id. at 6-8.

22 See discussion in Part II infra.

23114 F. Supp. 307 (D. Conn. 1953).

$241 d$. at 311.

25152 F. Supp. 387 (S.D.N.Y. 1957). 
bined sales amounted to about 13 per cent of the total sales of sugar, a portion of the market sufficiently large to persuade the court than any lessening of competition between the firms would be a substantial lessening in violation of section $7 . .^{28}$

The FTC had its first opportunity to examine amended section 7 in the Pillsbury Mills case. ${ }^{27}$ The evidence adduced in that case tended to show that Pillsbury by two acquisitions had appreciably increased its share of the market both in the southeastern part of the United States as well as nationally. ${ }^{28}$ Holding that this evidence was sufficiently probative to support the complaint, the commission reversed the order of the hearing examiner dismissing the complaint and commented on the construction to be given new section 7.28

\begin{abstract}
As we see it, amended Section 7 sought to reach the mergers embraced within its sphere in their incipiency, and to determime their legality by tests of its own. These are not the rule of reason of the Sherman Act, that is, unreasonable restraint of trade, nor are Section 7 prohibitions to be added to the list of per se violations. ${ }^{30}$ Somewhere in between is Section 7, which prohibits acts that "may" happen in a particular market, that looks to "a reasonable probability," to "substantial" economic consequences, to acts that "tend" to a result. Over all is the broad purpose to supplement the Sherman Act and to reach imcipient restraint.
\end{abstract}

Concluding then, it appears that in cases involving horizontal acquisitions, the test of section 7 of "substantially to lessen competition in any line of commerce" prohibits acquisitions adversely affecting a substantial share of a substantial market. And from the cases: Hamilton v. Benrus: to lessen competition in 20 per cent of the national watch market is prohibited; American Sugar: to lessen competition in 13 per cent of a ten-state sugar market is prohibited. But, International Shoe: to eliminate competition in less than 5 per cent of the national shoe market is not substantially to lessen competition. ${ }^{31}$

In addition to instances of horizontal acquisitions discussed above, "substantially to lessen competition" is also a test in cases of vertical acquisition. In $d u$ Pont-GM, although the action was based on the theory of violation of the tend to create monopoly clause of section 7 , the court established that one of the tests of monopoly is the power to "substantially lessen competition 'within the area of effective competition" "32 which was further defined as the power to foreclose competition in a substantial share of a substantial market. ${ }^{33}$ The Court's conclusion was:

26 Id. at $390-91,393,399-400$.

27 Dkt. 6000, 50 F.T.C. 555 (1953).

28 One of the acquired corporations selling solely in the southeastern market had formerly been third in the sale of family flour, third in sale of mixes, and ninth in sale of baking flour; the other had formerly been the fifth largest seller of mixes on the national market. As the result of the acquisitions, Pillsbury's position in the southeastern market alone was increased from fifth $(3 \%)$ to second $(8 \%)$ in the sale of family flour, from third $(4 \%)$ to first $(8 \%)$ in the sale of bakery flour, and its first place position in the sale of mixes was enlarged from $22 \%$ of the market to $45 \%$.

20 Id. at 569. Approval of this position is given by the REPORT OF THE ATTORNEY GeNERAr, STUDY OF TEE ANTITRUST Laws 122 (1955).

30 The per se doctrine refers to the Standard Stations decision discussed further in text at note 34 infra.

31 Since the committee reports for the 1950 amendment cited the International Shoe case with approval, H.R. Rep. No. 1191, 81st Cong., 1st Sess. 7 (1949), it should help frame the test. For the facts of the case see note 6 supra.

32353 U.S. at 593 .

33 Id. at 595 . 
[I]n order to establish a violation of $\S 7$ the Government must prove a likelihood that competition may be "foreclosed in a substantial share of ... [that market]." [Citing Standard Stations.] Both requirements are satisfied in this case. The substantiality of a relevant market comprising the automobile industry is undisputed. The substantiality of General Motor's share of that market is fully established in the evidence.

As appears from the excerpt above, the Court expressly relied on the Standard Stations case ${ }^{34}$ as authority for its final definition of the test of monopoly and by so doing equates the test of section 3 of the Clayton Act with that of section 7 . Perhaps because of uncertainties in interpretation, ${ }^{35}$ prior arguments that the test of Standard Stations should be apphed to actions under section 7 met with great resistance. ${ }^{36}$ That $d u$ Pont-GM unequivocally establishes this as the test is emphasized by the fact that, although the Court cites the Transamerica case $^{37}$ with approval, ${ }^{38}$ it is used as authority only for the necessity of establishing a market and its dicta ${ }^{39}$ rejecting the Standard Stations test in section 7 actions is carefully avoided. However, the Court, by its repeated einpliasis on the necessity of a market analysis in determining a violation, makes it clear that 'substantiality' does not mean mere dollar-size, independent of any inquiry regarding market, but rather refers only to the relative size of the portion of the relevant market affected.

\section{B. Tend to create a monopoly.}

The second test of new section 7, prohibiting acquisitions which may tend to create a monopoly, is substantially the same as it was under the old section. Presumably then, the test itself remains the same. Therefore, even though $d u$ Pont-GM was decided under old section 7, its interpretation should apply equally as well to cases subject to new section 7 .

$d u$ Pont-GM established that one test of a monopoly was the power to substantially lessen competition within the area of effective competition. Therefore, even thougl the action is being brought under the 'tend to create a monopoly' prohibition of section 7, it may be necessary to see if competition has been restricted in a substantial share of a substantial market, just as in actions under the first test of section 7.40

But the elimination of competition, while perhaps the most commouly thoughtof evil, is not the only anti-competitive influence that exists. For example, in the Transamerica case, ${ }^{41}$ the facts disclosed a combination of banks, which although it conducted over 50 per cent of the total banking business in a five state area,

34 Standard Oil Co. of California v. United States, 337 U.S. 293 (1949).

35 Some commentators read the Standard Stations case to mean that only a "quantitative substantiality" need be shown, independent of any inquiry regarding market. See, e.g., REPORT of the Attornex Generat, Stody OF the Antitrust La ws 141-44, especially n.58 (1955).

36 E.g., Transamerica Corp. v. Board of Governors, 206 F.2d 163, 170 (3d Cir. 1953); Pillsbury Mills, Inc., Dkt. 6000, 50 F.T.C. 555, 562-66 (1953); and see REPORT OF THE ATtORMEEY General, Study of THE ANTItrust Laws 122 (1955).

37 Transamerica Corp. v. Board of Governors of the Federal Reserve System, 206 F.2d 163 (3d Cir. 1953).

38353 U.S. at 592 .

30 Under close reading, the holding of Transamerica relates to the adequacy of the Board's findings, see 206 F.2d at 170 .

40 See text discussion at note 32 supra.

11 Transamerica Corp. v. Board of Governors of the Federal Reserve System, 206 F.2d 163 (3d Cir. 1953). 
had acquired no two banks in the same community. ${ }^{42}$ Since none of the banks directly competed against another, the court held that there was no lessening of competition. ${ }^{43}$ Furthermore, since there was no finding that the five state area was an area of effective competition, the court held that the Board of Governor's conclusion that there was a tendency to monopoly was unsupported. ${ }^{44}$ What the court failed to recognize was that there could be competitive evils other than mere impairment of direct competition by two neighboring banks. As one author has pointed out: ${ }^{45}$

The most significant economic fact emerging from the findings [of the Board] is the great size of the Transamerica banking holdings, both in absolute terms and in relation to other banks. No elaborate investigation was necessary to determine this. Bank of America alone is recognized as the largest commercial bank in the world. Such size obviously carries with it the possibility of harm to competition. A branch of the Bank of America is probably a more serious competitive threat to its rival in Middletown than would be a local independent bank-because of its greater financial backing if for no other reason, but also because of the advantages of organization, experience, reputation, diversification of risks and the like. The power of Bank of America to compete more effectively may be, for the same reasons, a power to drive out competition if the Bank should choose to do so and power to discourage competition whether it chooses to or not. Whether the power extends this far depends partly upon the extent of the advantage held and partly upon the strength of the deterrents against its exercise.

While as yet there has been little recognition of the fact that size alone may produce adverse economic effects sufficient to amount to a violation of the antitrust laws, ${ }^{46}$ such a concept would seem to have a proper place in both Sherman and Clayton Act prosecutions. In the Alcoa case, ${ }^{47} 90$ per cent control of an industry by one company was held to be a violation of the Sherman Act and the existence of unlawful practices was not considered essential. ${ }^{48}$ If the Clayton Act is designed to prevent "restraints of trade in their incipiency and before they develop into full-fledged restraints violative of the Sherman Act," ${ }^{40}$ perhaps some concept of actual size or tendency toward excessive size is an appropriate corrollary to the Alcoa concept.

However, some degree of vertical integration is obviously economically sound. In the Republic Steel case, ${ }^{50}$ for example, the court acknowledged as proper the apparent purpose behind Republic's acquisitions-“"to acquire additional and needed supplies of iron ore and coal and additional facilities supplementing its own, for the manufacture of pig iron and semifinished steel, and to bring about a reduction in costs of manufacture and distribution. . . . The net result will be better balanced facilities making possible manufacture at lowered costs." 51 . That

4

42 Id. at 168 .

43 Ibid.

$44 I d$. at 169 . The court even seems to suggest that no such finding could have been made because it "flies in the face of its . . . finding that the local community is the true competitive banking area." Ibid. However, there would seem hittle reason for assuming that the market inust be the saine for the purposes of both tests.

45 Neal, The Clayton Act and the Transamerica Case, 5 Staw. L. Rev. 179, 211 (1953).

46 But see United States v. Aluminum Co. of America, 148 F.2d 416 (2d Cir. 1945).

47 Ibid.

$48 I d$. at 425,432 .

40 S. Rep. No. 1775, 81st Cong., 2d Sess. 6 (1950), and see H.R. Rep. No. 1191, 81st Cong., 1st Sess. 8 (1949).

50 United States v. Republic Steel Corp., 11 F. Supp. 117 (N.D. Ohio 1935).

51 Id. at 125. 
such a process can exceed the permissible bounds of amended section 7 is apparent from the general disapproval ${ }^{52}$ of the Columbia Steel case. ${ }^{53}$ The House Judiciary Committee's report on the 1950 amendment intimated that new section 7 would prohibit the acquisition allowed in the Columbia Steel case which it described as the "acquisition of the largest steel fabricator on the west coast by the largest steel producer on the west coast (which itself is a subsidiary of the largest steel producer in the Nation). "54 The "tend to create a monopoly" clause of section 7 would seem the inost effective weapon against this form of combination.

\section{II}

\section{THE AMOUNT OF ACQUISITION-THE ELEMENT OF CONTROL}

In the discussion above, in order to determine what would constitute a 'substantial lessening of competition' or a 'tendency to monopoly' it was assumed that the acquired corporation was merged with the other. It now becomes necessary to examine the extent of the acquisition as a factor in determining a violation of section 7. For the purposes of this part of the discussion, it will be assumed that the test of market affects has been satisfied, thereby isolating 'control' as the sole remaining factor to be considered.

The amount of the acquisition relative to the total capital structure ${ }^{55}$ of the acquired firm will often determine the extent to which the acquiring firm will be able to bring about the effects proscribed by section 7 . Obviously, in cases of total acquisition, there can be little doubt of the ability of the acquiring corporation to control the policies of the acquired firm. However, control may also be obtamed by a 51 per cent stock acquisition or by even smaller amounts sufficient to establish working control. Where actual control, in any form, is achieved, the reasonable probability requirement of section 7 is clearly fulfilled. But even lesser amounts of stock holdings may be sufficient.

\section{Horizontal acquisitions.}

In cases of acquisitions of direct competitors, the anti-competitive effect threatened is the reduction of competition between the firms with a resultant substantial effect on the total market. Both the courts ${ }^{56}$ and the FTC ${ }^{57}$ liave established that the amount of stock acquired need not reach actual or working control proportions to violate new section 7 .

\footnotetext{
v2 See, e.g., Report of the Attorney General, Study of the Antitrust Laws 115-17 (1955).

53 United States v. Columbia Steel Co., 334 U.S. 495 (1948).

54 H.R. Rep. No. 1191, 81st Cong., 1st Sess. 10-11 (1949).

55 The following discussion, while limited in terms to stock acquisitions, is equally applicable to asset acquisitions under 'new' § 7. The revised language of the section was intended to prevent framing the transaction in the form of an asset acquisition and thus avoid 'old' $\$ 7$ which applied solely to stock. See note 7 supra. As worded, the section could be interpreted as including the outright purchase of additional 'assets,' such as buildings, etc., as well as some reorganizations which might technically be considered asset acquisitions. In view of the intent of the aniendment, however, the better interpretation would be to limit the section in its application solely to those forms of asset transactions which are mercly a substitute for stock acquisitions. Cf., INTERnaI Revenue Code of 1954, \& 368 (a) (1)(C).

58 American Crystal Sugar Co. v. Cuban-American Sugar Co., 152 F. Supp. 387 (S.D.N.Y. 1957) ; Hamilton Watch Co. v. Benrus Watch Co., 114 F. Supp. 307 (D. Conn. 1953).

57 Union Bag \& Paper Co., F.T.C. Dkt. 6391, CCH Trade REg. REP. \25,999 (1956) (allows retention of only $9 \%$ of stock under condition that it be non-voting); International Paper Co., F.T.C. Dkt. 6676, CCH Trade Reg. Rep. \26,560 (1957) (ordered sale of 12\% stock holding).
} 
In Hamilton v. Benrus, ${ }^{58}$ it was held that an acquisition sufficient to elect only one member to the board of directors of the acquired corporation, although clearly insufficient to give control, constituted a reasonable probability of producing the adverse effects on competition..$^{59}$ The court thought "it fairly inferable that minority representation, because of the opportunity thereby afforded to persuade or compel a relaxation of the full vigor of Hamilton's competitive effort would come within the ban of section 7." 00 The particular threat foreseen was that ${ }^{01}$

A director on Hamilton's board elected by Benrus would be in a position to obtain confidential information of value to Benrus as a competitor, the disclosure of which would be harmful to Hamilton and would materially impair its competitive position. ... Benrus would have power to discourage the vigor of competition by Hamilton and so to embarrass and impede Hamilton's management that it might well be driven to unwanted collaboration or to a merger as the lesser of two evils. 62

Nor is it essential that actual minority representation be achieved. In the American Sugar Co. case, ${ }^{63}$ although the acquiring corporation held 23 per cent of the stock of another sugar company, this was evidently not enough to obtain minority representation on the board. ${ }^{64}$ But the court reasoned that since the Clayton Act was designed to arrest restraints in their incipiency, the "statute obviously envisioned a situation where less than control of a competing corporation might be sufficient to be a violation. ..."65 Finding that the stock acquisitions were avowedly for the purpose of obtaining control, and that the acquiring corporation was in a financial position to continue the stock purchases, the court concluded that "unless restrained it may be anticipated that [the acquiring corporation] will pursue its program until it secured actual working control of the plaintiff company." 66

There are suggestions in the cases above of anti-competitive effects which might accrue from even smaller amounts of stock acquisition. For example, in the Hamilton case, the court found that "the association of Benrus' name with Hamilton as a consequence of the publicity given to Benrus' purchases of Hamilton stock has already impaired Hamilton's competitive position; ... it has impaired the effectiveness of Hamilton's vigorous new merchandising policy because of antagonism on the part of retail jewelers to Benrus' practices and reputation. ..." And in the American Sugar Co. case, the court found that the acquiring corpora-

58114 F. Supp. 307 (D. Conn. 1953).

59 At the time the suit was brought, Benrus owned $24 \%$ of the voting stock of Hamilton which, because of cumulative voting rights, would have been sufficient to elect one member of the board of Hamilton. However, there appeared to be ittle chance of Benrus obtaining control since about $40 \%$ of the stock was in a voting trust specifically organized to retain control in the face of the Benrus holding and the remainder of the stock, although not in the voting trust, was apparently friendly to it. Id. at 313-14.

60 Id. at 317 .

01 Id. at 314 .

62 In answer to the contention that such conduct would amount to divided loyalty and give rise to a derivative suit, the court stated: "Common experience has demonstrated that stockholders' suits, as a remedy for grievances growing out of such situations, are expensive and of doubtful efficacy." Ibid.

63 American Crystal Sugar Co. v. Cuban-American Sugar Co., 152 F. Supp. 387 (S.D.N.Y. 1957).

64 Cf. id. at 394 .

65 Id. at 395 .

66 Id. at 400 .

67114 F. Supp. at 314. 
tion "by means of its substantial stock holdings has succeeded in persuading officers of the plaintiff to furnish to it interim financial statements not generally made available to the public or other stockholders." "W8 Whether these effects would, by themselves, establish a violation of section 7 remains to be decided. ${ }^{69}$

\section{Vertical acquisitions.}

Conceivably, a violation of section 7 in cases of vertical acquisitions may require an acquisition of a greater proportion of stock, perhaps than necessary for actual control, than in cases of horizontal acquisitions. In the $d u$ Pont-GM case, for example, to establish a violation of section 7 it was necessary to prove a reasonable probability that the stock acquisition enabled du Pont to foreclose other prospective sellers from the General Motors' market. This would require that du Pont affirmatively influence or control General Motors' buying policies. Since one director on the board would certainly not 'control' the buying policies of the company in the face of an independent majority of directors, it is questionable whether the 'minority representation' theory of the Hamilton case would support a violation of this clause of section $7 .^{70}$

Of course, the amount of the stock acquisition should never be considered conclusive; a relatively insignificant stock holding may be prohibited where actual control or influence can be shown. The $d u$ Pont-GM case provides several indications of the evidence which may be utilized to establish such a showing. Evidence of common directors, of personnel holding positions in both firms, or of personnel in one firm who are' friendly to the other because of prior business connections would be indicative of a community of interest which might serve as the basis for influence. ${ }^{71}$ Equally indicative would be a shift in the pohicy of the acquired corporation in a manner favorable to the acquiring firm at or shortly after the acquisition, ${ }^{72}$ or a contmued course of dealing between the companies umiformly favorable to the acquiring corporation..$^{73}$ With all these factors present in $d u$ Pont-GM, it is not too surprising that the Court concluded that "the inference is overwhelming that du Pont's commanding position was promoted by its stock interest and was not gained solely on competitive merit." ${ }^{4}$ For those wlo may disagree with the word "overwhelining", the evidence is at least persuasive of the potential influence that du Pont has, or could have, over General Motors and thus adequate for a finding of a violation of section $7 .^{75}$

68152 F. Supp. at 394.

69 Even the court in the Hamilton case was careful to qualify the finding mentioned in text stbpra at note 67 as "at least, a prima facie" showing. $114 \mathrm{~F}$. Supp. at 314.

70 Of course, if a director could obtain "inside" information of such a nature as to give the acquiring corporation an unfair competitive advantage, such as advance knowledge of the amounts of the bids of competitors, the reasoning of the Hamilton case would be applicable. See quote at note 61 supra.

71 See, e.g., 353 U.S. at $601,602,604$.

72 See, e.g., 353 U.S. at 598-99.

73 See, e.g., 353 U.S. at 605 (the bulk of du Pont's production has always supplied the largest part of the requirements of [General Motors]).

74 Ibid.

75 In the picturesque language of the Court: "The fire that was kindled in 1917 continues to smolder . . . and if it has quieted down, it remains hot, and ... is likely at any time to blaze and make tbe fusion complete." Id. at 607. And see Business Week, June 8, 1957, p. 43, "An oversimplification, GM-Detroit builds and sells the cars; GM-New York manages the money. Curtice and his colleagues from Flint run GM-Detroit; du Pont runs GM-New York. Now the balance is going to have to change." 


\section{III \\ DU PONT TEST: "AT THE TTME OF SUIT"}

Perhaps the most significant aspect of the du Pont-GM decision is the holding that the test of section 7 is to be applied at the time of the suit. The appellees had insisted that the legality of the acquisition was to be determined as of the time of the acquisition. Therefore, since the stock in issue was acquired in 1917-1919, the government could not maintain the action in $1949 .{ }^{78}$ But the Court concluded that the philosophy of section 7-"to arrest monopolies in their incipiency and before consummation"177-required that an action be brought at any time the stock holding threatened to ripen into the prohibited effects. ${ }^{78}$ Further support for this conclusion, the Court felt, was given by the express provision of the section allowing an action whenever stock purchased for investment purposes was used to accomplish a prohibited effect. ${ }^{79}$

The net effect of this holding is to render illegal either the acquisition or the continued holding of stock if it can be shown to threaeten a violation of section 7.80 The impact of the time of suit test is that it will bring all acquisitions within the purview of the section irrespective of the date of the acquisition. ${ }^{81}$ If the issue was the legality at the time of the acquisition, that legality must be tested by the law then in effect. But where the test is the legality at the time of suit, it is the present law that is determinative. Although it has been suggested that such an application, at least as to asset acquisitions, would run afoul of the due process clause, ${ }^{82}$ such an objection seems purely illusory. ${ }^{83}$ The issue has long been settled as to the legal-

76353 U.S. at 596-97. Apparently, this conclusion was based on the theory that at the time of acquisition it would have been impossible to find any reasonable probability of the consummation of the effects prohibited by $\S 7$. Although there are some suggestions that the appellees were attempting to raise a laches argument to the effect that suits under $\S 7$ must be brought within a reasonable time after acquisition, Justice Burton expresses doubt that the doctrine of laches would apply against the government. Id. at 622-23 (dissenting opinion).

77 Id. at 597 , quoting from the report which accompanied the origimal bill in $1914, \mathrm{~S}$. Rep. No. 698, 63d Cong., 2 d Sess. 1.

78353 U.S. at 597.

79 Id. at 597-98. However, the dissent felt that expressly providing an exception in this one instance negatived any intent to allow such suits under the other parts of $\S 7$. Id. at 620 .

80 The dissent objected to this interpretation because it ignored what it felt was the allimportant lawfulness or unlawfulness of the acquisition at the time of suit. "The result is to subject a good-faith stock acquisition, lawful when made, to the hazard that the continued holding of the stock may make the acquisition illegal through unforeseen developments." 353 U.S. at 622 . The dissent further argued that the effect of the test was to render the originally lawful acquisition unlawful $a b$ initio. But any suggestions of retroactivity are clearly misconceived as is indicated in the text.

81 The Court in the $d u$ Pont-GM case felt that Clayton as amended was inapplicahle because the amendments "by their terms are inapplicable to acquisitions prior to 1950." 353 U.S. at 588 n.4. But the only suggestion in the amendment or the reports in support of the Court is found in the fifth paragraph of amended $\$ 7$ which states: "Nothing contained in this section shall be held to affect or impair any right heretofore legally acquired ...." But there is nothing that requires this to be construed as stating other than the rule that actions commenced prior to the date of enactment shall be governed by old $\$ 7$. As the text indicates, a right may bo 'legally acquired' and still become illegal subsequently. In any event, the question is not at issuo in the case since the action was commenced in 1949, before the amendment was enacted, and would be governed by old $\$ 7$ as the law in effect at the time of the suit.

$82 \mathrm{Cf}$. Adelman, The du Pont-General Motors Decision, 43 VA. L. Rev. 873, 878 (1957) (but our courts respect property rights, and would set aside any such long-delayed attempts to unscramble the eggs of a corporate omelet).

$83 \mathrm{~A}$ much more practical objection lies in the difficulty of separating assets once merger is counpleted. See, e.g., Farm Journal Inc., F.T.C. Dkt. 6388, CCH Trade Rea. REP. II 26,023 (1956). One magazine had purchased the assets of another magazine in a transaction which had 
ity of a law proscribing a course of conduct which may have been antecedently lawful. ${ }^{84}$ Indeed, it is difficult to see how economic regulation could ever have been effective if this were otherwise. The prediction of the dissent does seem extremely apt: "it now becomes apparent for the first time that $\S 7$ has been a sleeping giant all along." 85

Under the majority view, section 7 becomes an extremely effective remedy to prevent the formation of monopoly or adverse competitive conditions whenever it can be established that these conditions are threatened and stock acquisitions have been wholly or in part responsible. It does not require a showing of actual anticompetitive effects; "it would be unnecessary ... to speculate as to what is in the 'back of the minds' of those who promote a merger;"86 the only requisite is a showing of a threat of violation of section 7. Until such a showing is made, the acquiring firm may retain all its legitimate rewards. ${ }^{87}$

The general theory of section 7 is that the difference in economic justification between buying up your competition and forcing it out of the market by better competitive effort justifies the application of the more stringent safeguards of section 7 to the former while leaving the latter to Sherman Act action. ${ }^{88}$ To escape the more stringent safegaurds of the Clayton Act, increased concentration must have come from either internal expansion or by acquisition of firms "about to go under." 89 In both of the excluded situations, dominance represents the natural effect of free competitive forces in the market marking the industry, at least prima facie, as a "natural monopoly." Antitrust action is available then only under the Sherman Act upon a showing of severe deviations from proper economic performance..$^{91}$

been completed about one year before the hearing examiner found that it violated $\$ 7$. Faced with the problem of divestiture, the hearing examiner is quoted as having said: "Country Gentleman (the acquired corporation) is dead .... and the 'assets' which it turned over to the respondent are now without value to any newcomer or, indeed, to any farm publication now in the field. When his corn is taken from him and the horse dies, it is the height of vanity to strew the bare corncobs on his grave."

84 See, e.g., Northern Securities Co. v. United States, 193 U.S. 197 (1904).

85353 U.S. at 611 .

86 H. Rep. No. 1191, 81st Cong, 1st Sess. 8 (1949).

87 The legitimate rewards are not necessarily insignificant. U.S. News and World Report, June 14, 1957, p.122, reported that du Pont's stock holding was worth on today's market around 2.7 billion dollars representing a paper profit of 2.5 billion dollars and that over the years the dividends from the stock have amounted to more than 1.5 billion dollars.

88 The firm contemplating expansion has two choices: "If he builds, he creates additional capacity and competition, perhaps im an industry already well supplied; [but] if he buys, he reaps the possible advantages of increasing his capacity, acquiring some or all of the market previously served by a competitor, and at the same time may remove or nullify some competition in his market." Federat Trade Conarin, Report on Corporate Mergers aNd AcquisiTIONS 10 (1955).

88 That "a corporation with resources so depleted and the prospect of rehabilitation so remote that it is faced with the grave probability of a business failure" is excepted from $\S 7$ was first established by International Shoe Co. v. FTC, 280 U.S. 291, 302 (1950). The same exception will apply under 'new' § 7. See H.R. Rep. No. 1191, 81st Cong., 1st Sess. 6 (1949).

80 See Chadwell, Legal Tests for Violation of Section 2 of the Sherman Act and Section 7 of the Clayton Act in the Light of the Cellophane Opinion, 11 ANTITrust BuLr. 449, 453 (1957). "If monopoly results from the free play of competitive forces unencumbered by artificial restraints imposed by a monopolist, there is a strong presumption that it is probably the most suitable form of economic organization for the particular market where it exists."

01The limitations of $\S 1$ of the Sherman Act when applied to inergers are most sharply revealed by United States v. Columbia Steel Co., 334 U.S. 495 (1948), where the Court held that the acquisition of the largest steel fahricator on the west coast by the largest steel producer 
However, in some instances it may be difficult to distinguish between a firm whose dominant position was gained by acquisition rather than by internal expansion. For example, assume that the firm attained its present position of dominance by slow continuous expansion over the course of many years. Will the application of section 7 be deternined solely by the fact that, $\mathrm{m}$ one case, the firm made an acquisition of another firm at a time when both held only insignificant shares of the market, whereas another firm built its own additional capacity ${ }^{02}$ It is suggested that three different situations must be distinguished. Where there has been a history of many acquisitions, no one instance sufficient to amount to a violation, section 7 will be applicable when the cumulative effect has reached that amount necessary to constitute a violation..$^{03}$ Another situation calling for application of section 7 is that exemplified by the $d u$ Pont-GM case, where, although the acquisition was perhaps innocent at the outset, the conduct during the intervening years is such as to raise the inference that the "commanding position was prompted by [the] stock interest and was not gained solely on competitive merit." ${ }^{\prime 04}$ In the absence of either of these factors, the mere fact that the history of the dominant firm reveals insignificant acquisitions having no apparent relationship to the present position should not be sufficient to subject the firm to section 7 action.

The ease with which antitrust remedies can be applied in cases under section 7 greatly increases the desirability of Clayton Act actions. More often than not, following the acquisition, the acquired and the acquiring firms will be continued as separate business entities with, at most, some unification at the managerial level. Corrective action by division can be accoinphished simply by the restoration of the original operating units. ${ }^{05}$ In cases of mternal expansion, however, corrective action is more difficult. Divestment, in many cases requiring both vertical as well as horizontal separation into self-sustaining operating units, may prove an almost insurinountable obstacle.

\section{David D. Walkley and Theodore Zimmerman*}

on the west coast was not in violation of $\S 1$ because there was no showing that the actual cffect of such control was to unreasonably restrict the opportunities of competitors. Even granting that such a showing cannot be made, some argue that antitrust action should still lie. See, e.g., Stocking, Economic Tests of Monopoly and the Concept of the Relevant Market, 11 ANTITRUST BULL. 479, 482 (1957): "Bad performance may be an appropriate criterion for determining public policy towards a conpetitive industry [as in the regulation of the oil industry to prevent waste], but good performance can scarcely justify private monopolies in a society dedicated to free enterprise."

92 As was indicated earlier, while acquisition under "new" § 7 includes asset acquisitions, this must be limited to situations where the acquisition of assets is used in lieu of stock transactions which would otherwise be prohibited under $\$ 7$. See note 55 supra.

${ }^{83}$ See H.R. Rep. No. 1191, 81st Cong., 1st Sess. 8 (1949), quoted at note 20 stipra.

94353 U.S. at 605 ; see text discussion following note 70 supra.

95 Adequate relief can often be effected merely by destroying the legal forms used to accomplish the acquisition. For example, in some cases the stock may be rendered non-voting; sce, e.g., American Crystal Sugar Co. v. Cuban-American Sugar Co., 152 F. Supp. 387 (S.D.N.Y. 1957) ; Hamilton Watch Co. v. Benrus Watch Co., 114 F. Supp. 307 (D. Conn. 1953); Union Bag \& Paper Co., F.T.C. Dkt. 6391, CCH Trade Reg. Rep. 10 25,999 (1956); and see generally, Report of the AtTORNey GeneraI, Study of the ANTItrust Laws 353-58 (1955). In other cases, the stock may be ordered sold; see, e.g., Union Bag \& Paper Co., F.T.C. Dkt. 6391, CCH Trade Reg. Rep. 7 25,999 (1956); Crown Zellerbach Corp., F.T.C. Dkt. 6180, CCF Trade Reg. REP. $\int 26,397$ (1957). For an insight into some of the practical problems that beset an order to sell a substantial block of stock, see discussion in Busmess Week, June 8, 1957, p. 43; U.S. News \& World Report, June 14, 1957, pp. 122, 124, concerning the tax consequences and market effects which might arise froin the divestiture by sale of du Pont's holding of GM stock.

* Members, Third-Year Class. 